\title{
PERANCANGAN HUNIAN SEWA UNTUK MILENIAL DI PADEMANGAN
}

\author{
Fanuel Fang ${ }^{1)}$, Rudy Surya ${ }^{2)}$ \\ 1)Program Studi S1 Arsitektur, Fakultas Teknik, Universitas Tarumanagara, fangfanuel@gmail.com \\ 2) Program Studi S1 Arsitektur, Fakultas Teknik, Universitas Tarumanagara, rudys@ftuntar.ac.id
}

\begin{abstract}
Abstrak
Urbanisasi telah menjadi fenomena yang umum terjadi di kota besar, tanpa terkecuali Jakarta. Kaum urban (sebutan untuk orang yang melakukan urbanisasi) biasanya datang ke Jakarta untuk mendapatkan pekerjaan dengan upah lebih tinggi dibandingkan daerah asal mereka. Karenanya, pengeluaran selama berada di Jakarta diminimalisir sebisa mungkin, termasuk dalam hal memilih tempat tinggal sementara. Hal inilah yang ikut mengakibatkan munculnya pemukiman kumuh di ibukota, sebagaimana yang terjadi di Kelurahan Pademangan Barat. Para pendatang yang didominasi generasi milenial ini mayoritas berprofesi sebagai karyawan toko di Mangga Dua dan buruh konveksi. Mereka menempati bangunan semi dan nonpermanen di gang-gang sempit, bahkan hingga memenuhi sepanjang pinggir rel kereta api yang melintas di Pademangan, dimana semestinya merupakan jalur hijau. Keberadaan hunian seperti inilah yang membuat Kawasan Pademangan Barat terkesan kumuh, padat dengan bangunan, dan kehilangan ruang hijaunya. Meski hanya berupa bangunan berbahan triplek kayu yang menumpang di dinding pembatas rel kereta, namun kamar-kamar yang disewakan ini begitu diminati bahkan hingga kelebihan kapasitas. Hal ini dikarenakan harga sewanya yang murah dan cukup untuk memenuhi kebutuhan penghuni yang hanya memerlukan tempat beristirahat sementara. Pemerintah sebenarnya telah menyediakan rumah susun murah di Kemayoran, namun tampaknya berpengaruh dalam mengurangi hunian kumuh ini. Hunian sewa vertikal yang sekaligus menyediakan fasilitas bersama, turut berperan sebagai ruang hijau untuk mengimbangi kepadatan bangunan yang ada di Pademangan. Sehingga tidak hanya diperuntukkan bagi penghuni, namun juga dapat digunakan oleh warga sekitarnya, dimana berdasarkan analisa penulis berlokasi di RW 10 Kelurahan Pademangan Barat.
\end{abstract}

Kata kunci: Fasilitas; Hunian; Milenial; Pola; Urbanisasi

\begin{abstract}
Urbanization has become a common phenomenon in big cities, with the exception of Jakarta. Urbanites (the name for people who are urbanizing) usually come to Jakarta to get jobs with higher wages than their home regions. Although the cost of living in Jakarta is relatively expensive, large revenues are the main focus for them. This is what has contributed to the emergence of slums in the capital, as happened in Pademangan Barat Village. The majority of migrants dominated by millennials work as shop employees in Mangga Dua and labor convection. They occupy semi-permanent buildings in narrow alleys, even to the extent that they fill along the edge of the railroad tracks that pass in Pademangan, which should be a green line. The existence of such housing makes the West Pademangan Area seem dingy, crowded with buildings, and loses its green space. This is because the rental price is cheap and sufficient to meet the needs of residents who only need a temporary resting place. The government has actually provided low-cost flats in Kemayoran, but it seems influential in reducing these slum dwellings. Vertical rental housing which simultaneously provides shared facilities also plays a role as a green space to compensate for the density of buildings in Pademangan. So that not only intended for residents, but also can be used by the surrounding residents, where analyzed by the author to be located in $10^{\text {th }} \mathrm{RW}$ (citizen association) of Pademangan Barat.
\end{abstract}

Keywords: Facilites; Housing; Millennial; Pattern; Urbanization 


\section{PENDAHULUAN}

Latar Belakang

Generasi milenial (disebut juga generasi Y) yang lahir antara tahun 1980 hingga 2000 (menurut riset global Goldman Sachs) saat ini menduduki populasi usia produktif terbanyak di dunia. Tentu saja dengan demikian keberadaan mereka memberi dampak yang begitu besar terhadap perkembangan dunia. Telah banyak isu dan penelitian yang dilakukan di seluruh dunia untuk membahas mengenai karakter dan perilaku generasi ini. Dengan wilayah dan latar belakang yang berbeda, tentu bisa membentuk karakter dan perilaku milenial yang berbeda pula, sehingga untuk menyelesaikan permasalahan milenial di suatu wilayah perlu memahami konteks lingkungannya. Penulis memilih untuk mengangkat isu milenial pada skala kelurahan, dan lokasi yang dipilih yaitu kawasan Pademangan.

Pademangan merupakan sebuah kawasan pemukiman penduduk yang berlokasi di Jakarta Utara. Wilayah Pademangan menjadi penting karena berperan sebagai penunjang kawasan perniagaan Mangga Dua. Pademangan banyak dihuni oleh pekerja kelas rendah, maupun pekerja sektor informal. Dan sebagaimana umumnya yang terjadi di kawasan padat penduduk di Jakarta, permasalahan yang terdapat di Pademangan adalah terkait keberadaan pemukiman kumuh dan keterbatasan fasilitas publik sebagai kebutuhan penunjang kawasan pemukiman.

Berdasarkan hasil pengamatan dan analisis penulis, maka kawasan yang dinilai perlu untuk segera dibenahi dan menjadi target proyek ini adalah pemukiman di sepanjang rel kereta, terutama di lingkup RW 10 Kelurahan Pademangan Barat. Adapun pemukiman kumuh di kawasan tersebut kebanyakan merupakan kost-kostan dengan bangunan semi permanen. Dihuni oleh pendatang dari berbagai wilayah, yang memilih untuk meninggalkan keluarganya di kampung, dan merantau ke Jakarta seorang diri. Kaum urban (sebutan untuk orang yang melakukan urbanisasi) ini berasal dari usia yang beragam dan berada di rentang usia kerja, sehingga dominan oleh generasi milenial. Bahkan karena banyaknya, sebanyak 60\% warga RW 10 Kelurahan Pademangan Barat merupakan pendatang, sedangkan warga aslinya hanya sekitar $40 \%$. Selain itu dikarenakan kebutuhan akan hunian yang tinggi, hampir tidak dapat ditemukan lahan hijau serta fasilitas untuk olahraga dan berkomunitas di Pademangan. Karenanya Pademangan menjadi terkesan sumpek dan terlalu padat bagi warga yang tinggal disana.

Karena itu, diperlukan upaya untuk membenahi wilayah Pademangan, khususnya di RW 10 serta di sepanjang jalur kereta di Kelurahan Pademangan Barat. Diharapkan penerapan arsitektur melalui perencanaan dan program yang tepat dapat meningkatkan kualitas hidup masyarakat Pademangan di kemudian hari.

\section{Susunan Penulisan}

Isi makalah terdiri dari bagian Pendahuluan, Kajian Literatur, Metode Penelitian, Hasil Penelitian dan Analisis, Kesimpulan dan Saran, dan diakhiri dengan Bibliografi. Bagian pendahuluan menjelaskan latar belakang isu atau masalah yang diangkat, urgensi isu, pertanyaan penelitian, batasan masalah, dan tujuan penelitian. Bagian kajian literatur membahas mengenai landasan teori dan literatur yang menjadi dasar pembahasan perancangan. Bagian metode penelitian menjelaskan metode yang digunakan dalam meneliti kawasan dan merancang proyek.

Hasil Penelitian dan Analisis membahas tentang proses berpikir dan rancangan yang dihasilkan.

\section{KAJIAN LITERATUR}

\section{Tipe dan Tipologi}

Kata tipe berasal dari Bahasa Yunani 'typos' yang berarti pengelompokkan, sedangkan menurut KBBI, tipe berarti model, contoh, corak. Sedangkan tipologi berasal dari dua kata yaitu 'typos' dan 'logia' yaitu ilmu yang mempelajari tentang sesuatu. Sehingganya tipologi 
didefinisikan sebagai ilmu yang mempelajari segala sesuatu yang berkenaan dengan tipe (Budi A. Sukada, 1984).

Sedangkan menurut Rafael Moneo dalam jurnal "On Typology", tipe bisa didefinisikan sebagai sebuah konsep yang menjelaskan sekelompok objek yang dicirikan dengan struktur formal yang sama. Namun objek yang diciptakan arsitektur tidak hanya digambarkan dengan tipe, namun juga dihasilkan olehnya. Arsitek memulai dari tipe yang ia ketahui, namun kemudian ia bisa mengambil tindakan menghancurkannya, mengubahnya, atau menyelaraskannya. Proses desain adalah cara menghadirkan unsur unsur tipologi - gagasan tentang struktur formal - ke dalam wujud tepat yang menjadi ciri karyanya.

Selanjutnya, Alan Colquhoun mengemukakan dalam komunikasi antara arsitektur dan masyarakat, arsitek menguasai makna, dan melaluinya dapat masuk ke dalam proses transformasi masyarakat. Tipe diwarnai oleh konten ideologis dan makna dalam kerangka kerja dimana arsitektur dibuat. Tipe menjadi media bagi makna karya yang diciptakan arsitek.

Konsep tipe itu sendiri terbuka terhadap perubahan. Bagian dari yang usang dalam tipe dapat diubah untuk menghasilkan arsitektur yang memandang ke masa depan. Dalam proses transformasi yang berkelanjutan ini, arsitek dapat mengubah kegunaannya, mengubah skala cakupan tipe, atau menggabungkan dengan tipe yang berbeda untuk menghasilkan tipe baru, itulah fungsi dari penciptaan oleh seorang arsitek.

\section{Tipe dan Perilaku dalam Arsitektur}

Dalam konteks arsitektural, arsitek dapat mengambil peran sebagai yang mengawali, dimana arsitek mendesain dan mengkondisikan ruang untuk memenuhi program yang dibutuhkan, yang mana pada akhirnya akan jatuh ke tangan pengguna yang terdampak oleh program aktivitas dari elemen ruang dan arsitektur.

Lingkungan tidak hanya menjadi 'sesuatu', namun memiliki kapasitas memberikan makna kepada manusia yang terlibat, sehingga menggerakkan mereka untuk memberi respon dan berinteraksi dengan lingkungannya. Karena itu, desain yang sukses tidak hanya mengenai bagaimana bangunan arsitektur membentuk ktia, tapi juga membuat orang merasa bahwa mereka memiliki peran terhadap lingkungannya. Diri kita adalah pribadi yang dimana lingkungan kita ditempatkan.

\section{Generasi Milenial dan Perilakunya}

Generasi $Y$ atau Milenial adalah mereka yang lahir antara awal tahun 1980an hingga awal tahun 2000an. Dikenal canggih, melek teknologi, kebal terhadap teknik pemasaran tradisional, mereka telah melihat semua hal itu sejak usia dini. Generasi milenial menjadi topik penting saat ini karena populasi mereka yang mendominasi saat ini, serta usia mereka yang kini sedang dalam usia produktif.

Menurut riset global Goldman Sachs, milenial memiliki dunia dan pandangan yang berbeda. Milenial tumbuh di masa perubahan yang cepat, memberi mereka serangkaian prioritas dan ekspektasi yang sangat berbeda dari generasi sebelumnya. Milenial merupakan generasi pertama yang terlahir di dunia digital. Mereka terhubung dengan dunia sosial. Tingkat pekerjaan yang rendah dan penghasilan yang lebih kecil membuat mereka memiliki uang lebih sedikit ketimbang generasi sebelumnya. Hal ini berdampak pula pada menurunnya prioritas untuk menikah dan memiliki rumah.

Sejumlah penelitian dan pengamatan tentang milenial terkait dengan hunian menunjukkan bahwa generasi milenial cenderung memilih hunian vertikal berupa unit-unit kamar yang disewakan ketimbang hunian tapak. Riset lain terkait kesehatan menunjukkan bahwa generasi milenial memiliki risiko terkena kanker, diabetes, dan juga penyakit jantung yang lebih tinggi sebagai akibat dari masalah pekerjaan, hubungan sosial, dan juga tempat tinggal. Selain masalah kesehatan, generasi milenial juga mengalami krisis dalam interaksi sosial, terkait dengan penggunaan ponsel pintar, dimana mereka sangat banyak berinteraksi dengan gadget. Kebiasaan 
tersebut menyebabkan kemampuan para generasi milenial dalam berinteraksi dengan manusia menjadi rendah. Hal ini kemudian memengaruhi kepercayaan diri mereka ketika berbicara di depan umum. Mungkin mereka bisa sangat aktif dalam memberikan komentar di media sosial, tapi ketika interaksi langsung mereka kurang.

\section{Rumah Susun}

Rumah susun adalah bangunan gedung bertingkat yang dibangun dalam suatu lingkungan yang terbagi dalam bagian-bagian yang distrukturkan secara fungsional, baik dalam arah horizontal maupun vertikal dan merupakan satuan-satuan yang masing-masing dapat dimiliki dan digunakan secara terpisah, terutama untuk tempat hunian yang dilengkapi dengan bagian bersama, benda bersama, dan tanah bersama. (Undang Undang Republik Indonesia Nomor 20 Tahun 2011 tentang Rumah Susun). Pembangunan rumah susun umum, rumah susun khusus, dan rumah susun negara merupakan tanggung jawab pemerintah. Sedangkan pembangunan rumah susun komersial dapat dilaksanakan oleh setiap orang.

Adapun beberapa tujuan penyelenggaraan rumah susun antara lain yaitu menjamin terwujudnya rumah susun yang layak huni dan terjangkau; meningkatkan efisiensi dan efektivitas pemanfaatan ruang dan tanah; menyediakan ruang terbuka hijau di kawasan perkotaan dalam menciptakan kawasan permukiman yang lengkap serta serasi dan seimbang; mengurangi luasan dan mencegah timbulnya perumahan dan permukiman kumuh; memenuhi kebutuhan sosial dan ekonomi yang menunjang kehidupan penghuni dan masyarakat dengan tetap mengutamakan tujuan pemenuhan kebutuhan perumahan dan permukiman yang layak, terutama bagi masyarakat berpenghasilan rendah (MBR);

\section{METODE}

Metode yang digunakan penulis dalam menghasilkan desain bangunan adalah shape grammar (tata bahasa wujud). Metode yang dipelopori oleh George Stiny menawarkan "shape grammar" sebagai cara penyelesaian rancangan. Dia meneliti rancangan arsitek besar seperti Frank Lloyd Wright, dan Le Corbusier dan menemukan dalam karya-karya mereka selalu ada semacam tata Bahasa yang mengatur wujud akhir perancangannya.

Wujud (shape) memiliki sifat-sifat yang memungkinkannya berhubungan dengan wujud lain atau yang sejenis. Dari situ perancang dapat mengatur bagaimana aturan itu berlaku agar hubungan wujud tersebut bermakna. Untuk itu, dalam permainan tata bahasa wujud, kita perlu menentukan terlebih dahulu wujud asalnya. Bila bujur sangkar sebagai wujud asal, maka perancang perlu mengungkapkan kebujursangkarannya. Bila kubus sebagai wujud asal, maka perancang perlu menguraikan kekubusannya. Dalam permainan ini, sebaiknya pemula memulainya dengan selangkah-demi selangkah, dari yang mudah ke yang sulit.

Setelah menentukan sifat wujud asal, perancang dapat mulai mencari hubungan keruangan wujud tadi dengan wujud yang serupa dalam hal dia hanya memainkan satu wujud mula. Bila dalam permainan dia melibatkan lebih daripada satu wujud sebagai wujud-wujud mula, maka wujud-wujud lain perlu diperlakukannya seperti wujud pertama. Dia mencatat setiap kemungkinan hubungan tanpa pengulangan.

Dengan Spesifikasi hubungan keruangan, perancang memiliki cukup perbendaharaan terhadap kemungkinan penggabungan antar unsur atau sifat wujud. Langkah berikutnya adalah, dia perlu mengatur kemungkinan tersebut dalam serangkaian aturan main yang dikenal sebagai aturanaturan wujud atau shape rules.

Tata Bahasa di sini analog dengan matematik dan geometri, bukan dengan bahasa tuturan biasa. Perancang dapat menyertakan penambahan, pengurangan, perkalian, dan pembagian yang berlaku dalam ilmu hitung dalam permainan ini. Selain itu dia juga dapat memakai cara perputaran, pencerminan, pergeseran, dan pembalikan dalam aturan-aturannya. Pada aturan yang menghasilkan sebuah wujud baru, Stiny menamakannya aturan komposisi. Dalam rangkaian aturan, langkah-langkahnya perlu sejelas mungkin sehingga tidak menimbulkan penafsiran ganda. 


\section{DISKUSI DAN HASIL}

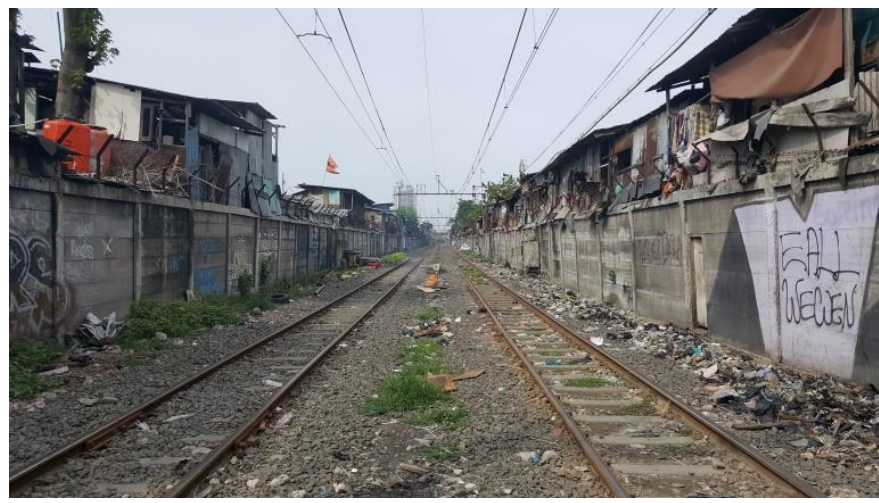

Gambar 1. Pemukiman kumuh yang menempati sepanjang pinggir rel kereta di Pademangan Sumber: Penulis, 2019

Dari hasil pengumpulan data melalui pengamatan dan wawancara yang dilakukan penulis kepada sejumlah milenial di Pademangan, diketahui bahwa permasalahan dasar yang dirasakan warga terhadap lingkungan Pademangan adalah mengenai kepadatan bangunan dan kebutuhan akan ruang terbuka dan fasilitas publik. Dimana lahan di Pademangan hampir seluruhnya telah dipadati hunian, namun tidak diimbangi dengan fasilitas sosial, olahraga, dan ruang terbuka hijau. Pemukiman yang ada bahkan seringkali melebihi kapasitas huni, sehingga memberi kesan kumuh. Selain itu banyak pemukiman illegal yang dibangun diatas lahan di sepanjang rel kereta yang melintasi daerah Pademangan, yang semestinya merupkaan area hijau.

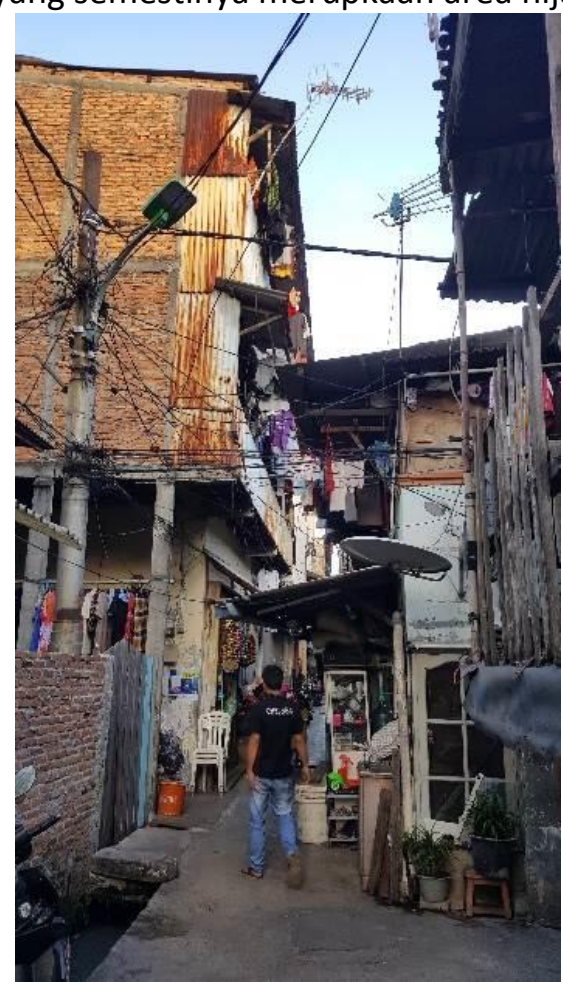

Gambar 2. Suasana salah satu hunian kumuh di Pademangan Sumber: Penulis, 2019

Wawancara langsung dengan warga dan pengurus di lingkungan tersebut memberikan gambaran lebih mendalam. Didapat informasi bahwa hampir semua masyarakat yang menghuni pemukiman kumuh merupakan pendatang dari luar kota. Mereka biasanya datang seorang diri, sedangkan keluarga asli mereka berada di kampung. Profesi mereka kebanyakan adalah karyawan 
toko di Mangga Dua, atau sebagai buruh konveksi. Dan karena mencari tempat tinggal yang murah, mereka memilih menetap di pemukiman tersebut. Bangunan-bangunan ini biasanya berupa kamar-kamar yang disewakan, dengan ukuran kamar 2 meter $\times 3$ meter yang dihuni 2-3 orang tiap kamarnya. Untuk keperluan mandi biasanya mereka menggunakan tempat MCK umum diluar rumah. Selain itu tidak terdapat dapur karena mereka biasanya langsung membeli makanan jadi dan tidak ada waktu untuk memasak.

Selain itu hasil kuisioner yang penulis sebarkan, yang diikuti oleh 60 warga (30 pria dan 30 wanita) Pademangan tahun menemukan karakter dan perilaku masyarakat yang ada di Pademangan. Dimana menurut hasil kuisioner, milenial di Pademangan cenderung lebih banyak menghabiskan waktunya di kamar, jarang melakukan interaksi langsung dan lebih banyak berinteraksi dengan gadget. Bermain gadget telah menjadi hiburan utama warga, sehubung juga dengan pernyataan responden bahwa ruang publik untuk bersosial di Pademangan masih sangat kurang. Menurut mereka, kegiatan yang dapat melepaskan diri dari ketergantungan gadget adalah dengan berinteraksi sosial/ bermain dengan teman, berolahraga, jalan-jalan dan membaca. Sayangnya keberadaan tempat-tempat seperti ini masih minim di Pademangan.

Hampir seluruh responden berpendapat bahwa olahraga penting, bahkan perlu dilakukan setiap hari. Meski demikian, sebagian besar responden memiliki intensitas olahraga yang rendah. Bahkan hasil respon terbanyak adalah responden belum tentu berolahraga dalam seminggu. Lokasi untuk berolahraga juga masih sangat kurang, dimana lokasi tujuan yang biasanya dikunjungi warga untuk berolahraga ialah Ancol. Itupun berbayar dan hanya dikunjungi di akhir minggu. Akibatnya, warga kebanyakan hanya bisa menongkrong di warung, di depan rumah, bahkan di rel kereta. Anak-anak juga tidak memiliki tempat bermain sehingga mereka biasanya bermain bola di jalan, atau bermain di rel kereta.

Melihat kondisi demikian, maka dari hasil analisa penulis, hal pertama yang perlu dilakukan adalah melakukan pembenahan terhadap bangunan-bangunan yang kumuh dan tidak layak. Bangunan-bangunan tersebut nantinya akan ditata dan dimaksimalkan ketinggiannya sehingga dapat menyisakan ruang yang bisa dijadikan tempat fasilitas bersama. Dan diketahui bahwa fasilitas yang saat ini dibutuhkan berupa ruang terbuka hijau, beserta fasilitas olahraga dan sarana bagi warga untuk berkomunitas. Karena itu tahapan selanjutnya ialah memilih lokasi yang tepat untuk dibenahi. Dan setelah melalui proses seleksi dan pertimbangan, tapak terpilih berada di Jalan Budi Mulya, RT 9 RW 10 Kelurahan Pademangan Barat. Tapak memiliki luas 3000 m²$^{2}$, dengan KDB 60\%, KLB 2.4, KDH 30\%, dan KB 4 lantai.

Berangkat dari permasalahan yang coba diselesaikan di tapak, terkait dengan pembenahan lingkungan hidup, yakni dari kekumuhan dan ketersediaan ruang publik, maka yang menjadi konsep dari perancangan adalah keteraturan pola. Dari yang semula tidak teratur, tidak berpola, semua membangun dengan kemauan sendiri tanpa mengikuti standar kelayakan yang semestinya, menjadi sesuatu yang terlihat teratur, memiliki pola, tanpa mengubah fungsi yang ada di dalamnya. Termasuk dalam keteraturan pola tersebut, melibatkan unsur pencahayaan dan pengudaraan alami, yang selama ini tidak terjamah terutama oleh bangunan kumuh di Pademangan, yang berada dalam gang-gang sempit, lembab, dengan kepadatan tinggi. Sehingga hunian baru ini bisa menciptakan suasana baru yang sebelumnya mungkin belum pernah dirasakan. 


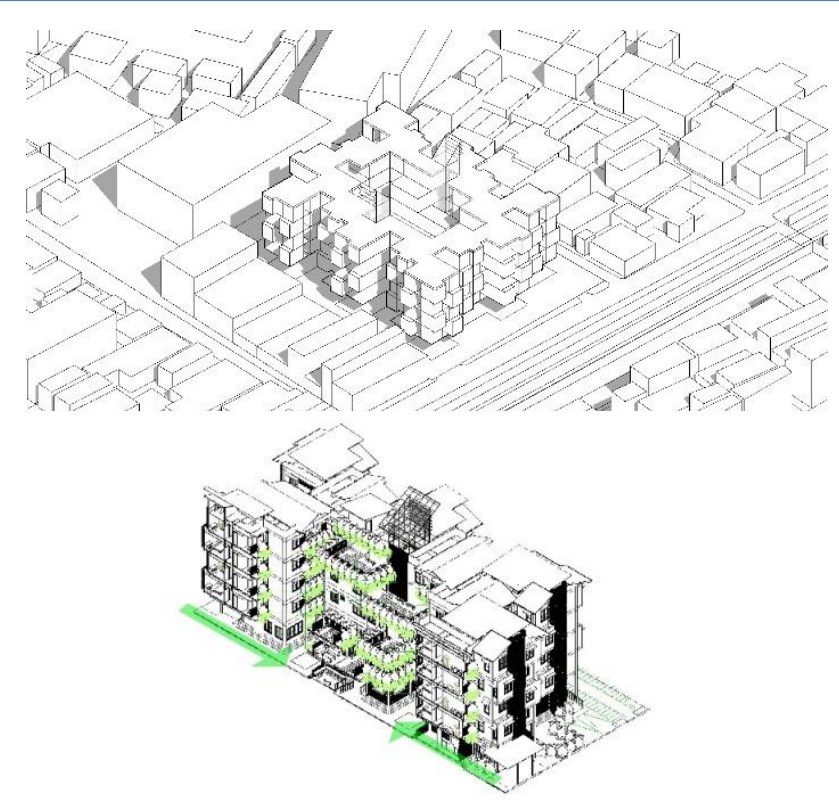

Gambar 3. Aksonometri massa bangunan

Sumber: Penulis, 2019

Proses terbentuknya massa bangunan berawal dari studi tentang ruang gerak kebutuhan unit yang menghasilkan modul dasar unit terkecil berukuran 3 meter $\times 3$ meter. Selanjutnya unit tersebut dijadikan satu grup yang terdiri dari 4 unit, dan kemudian menggabungkan 2 grup unit menjadi satu cluster yang dilengkapi dengan dapur, kamar mandi, dan area makan. Pola cluster diterapkan secara berulang ke dalam tapak dengan formasi seluas mungkin, untuk memperoleh kapasitas unit yang maksimal, dan kemudian diduplikasikan secara vertikal menjadi 4 lantai. Dari massa yang terbentuk, diberi void dan area komunal di pusat massa, dilanjutkan dengan permainan pola maju mundur unit dan pemisahan area hunian dengan area publik di lantai dasar,

Dari segi pengadaan ruang publik, maka perlu ada ketegasan yang jelas antara hunian dengan area publik, sehingga lantai dasar perlu dirancang agar bersifat terbuka, bisa dinikmati siapa saja, dan dipisahkan dari area hunian dengan menaikkan level hunian ke tingkat ke dua. Jenis ruang publik yang diadakan dirancang mengandung unsur ruang terbuka, penghijauan, rekreasi, olahraga, dan interaksi sosial, mengingat hasil penelitian yang sebelumnya dibahas menunjukkan tidak difasilitasinya unsur-unsur tersebut. Unsur penghijauan dihadirkan mengingat bahwa hal tersebut merupakan hal yang cukup langka ditemukan di Pademangan, sehingga keberadaan penghijauan dapat membantu membentuk suasana serta mengimbangi kepadatan di Pademangan.

Lantai dasar menjadi ruang publik, yang dapat diakses dari jalan utama, maupun dari arah pasar, sehingga menjadi penghubung, dan memiliki potensi komersil.Void di tengah dengan roof garden yang bertingkat memungkinkan jangkauan sinar matahari menerangi hingga lantai dasar. Roof garden dibuat dengan tingkat yang berbeda-beda agar cahaya matahari dapat menyinari seluruh roof garden. Skema aliran udara yang diciptakan dari penangkap angin, dialirkan menuju lantai dasar sehingga terjadi sirkulasi udara. 


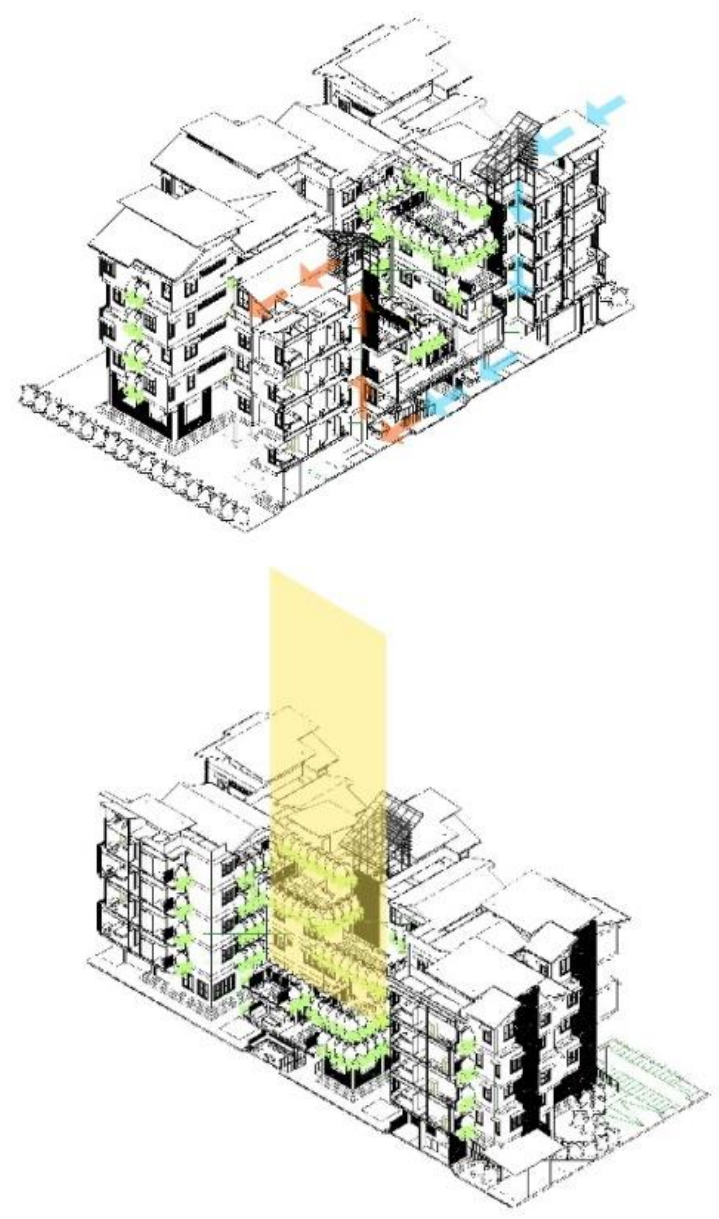

Gambar 7. Skema cahaya matahari pada void Sumber: Penulis, 2019

\section{KESIMPULAN DAN SARAN}

Proyek "Hunian Sewa untuk Milenial" merupakan respon untuk menjawab permasalahan lingkungan hidup yang ada di Pademangan. Permasalahan yang dimaksud meliputi keberadaan pemukiman yang kumuh dan ilegal, serta kebutuhan akan ruang publik untuk kegiatan seperti interaksi sosial, olahraga dan tempat bermain anak. Diharapkan dengan adanya proyek ini, pemukiman kumuh yang ada di Pademangan bisa ditingkatkan kualitasnya agar memenuhi standar hunian yang layak, serta dapat menjadi wadah berinteraksi, berekreasi dan berolahraga bagi warga.

Desain proyek ini sekaligus dirancang untuk mencapai tujuan yang ada dalam "Sustainable Development Goals", pada aspek "Good Health and Well-Being", yaitu menjamin hidup sehat dan kesejahteraan untuk semua usia di segala usia dengan membentuk gaya hidup sehat bagi masyarakat untuk berolahraga. Aspek kedua yakni "Affordable and Clean Energy", yaitu menjamin akses ke energi yang terjangkau, andal, berkelanjutan, dengan bangunan yang hemat energi dengan memanfaatkan pencahayaan dan penghawaan alami. Dan aspek ketiga "Sustainable Cities and Communities", yaitu menjadikan kota dan pemukiman manusia yang inklusif, aman, tangguh, dan berkelanjutan, dengan memastikan keberadaan fasilitas yang memadai untuk mendukung masyarakat yang tinggal, dalam proyek ini yaitu ruang hijau, fasilitas olahraga, dan ruang komunitas.

Kiranya modul dan pola yang dirancang dalam proyek ini dapat menjadi prototipe yang dapat diterapkan di lokasi-lokasi lain dengan permasalahan yang sesuai kondisi masyarakat di lingkungannya masing-masing. 


\section{REFERENSI}

Agudin, L. M. (1995). The Concept of Type in Architecture: An Inquiry into the Nature of Architectural

Bond, M. (6 Juni 2017). The Hidden Ways That Architecture Affects How You Feel. Diunduh 23 Januari 2019, dari BBC: http://www.bbc.com/future/story/20170605-the-psychology-behindyour-citys-design

Dinas Komunikasi, Informatika dan Statistik Pemprov DKI Jakarta. PADEMANGAN, KECAMATAN. Diunduh 17 Februari 2019: https://jakarta.go.id/artikel/konten/3284/pademangan-kecamatan

Fajrina, H. N. (14 Juli 2016). Generasi Millennial Manfaatkan Ponsel untuk Hindari Interaksi. Diunduh 23 Januari 2019, dari CNN Indonesia: https://www.cnnindonesia.com/teknologi/20160714100723-185-144678/generasi-millennialmanfaatkan-ponsel-untuk-hindari-interaksi

Fourhooks. (26 April 2015). The Generation Guide - Millennials, Gen X, Y, Z and Baby Boomers. Diunduh 23 Januari 2019, dari Fourhooks: http://fourhooks.com/marketing/the-generationguide-millennials-gen-x-y-z-and-baby-boomers-art5910718593/

Goldman Sachs. (2019). MILLENNIALS COMING OF AGE. Diunduh 23 Januari 2019, dari Goldman Sachs: https://www.goldmansachs.com/insights/archive/millennials/

Haryanti, R. (28 Januari 20190). Milenial, Sasaran Potensial Pengembang Properti. Diunduh 24 Maret 2019, dari Kompas.com: https://properti.kompas.com/read/2019/01/28/184303821/milenial-sasaran-potensialpengembang-properti

Kamus Besar Bahasa Indonesia. Diunduh 23 januari 2019, dari KBBI: https://kbbi.web.id/tipe

Koran SINDO, Jurnalis. (29 Maret 2017). Pentingnya Generasi Milenial Sadari Kebutuhan Hunian. Diunduh 24 Maret 2019, dari Okezone: https://economy.okezone.com/read/2017/03/29/470/1653424/pentingnya-generasi-milenialsadari-kebutuhan-hunian

Kusuma, D. W. (3 Desember 2018). Gaya Hidup Pengaruhi Kesehatan Generasi Millennial. Diunduh 23 Januari 2019, dari Lampung Post: http://sehat.lampungpost.id/kesehatan/gayahidup-pengaruhi-kesehatan-generasi-millennial/

Mah, K. (15 April 2013). Architecture \& The Human Behaviour. Diunduh 23 Januari 2019, dari Academia: https://www.academia.edu/7383370/Architecture_and_the_Human_Behaviour

Moneo, R. (1978). On Typology. Oppositions, 22-45

Mullaney, J. (28 Juni 2018). A New Study Finds Millennials Are The First Generation on Track to Be Less Healthy Than Their Parents By Middle Age. Diunduh 23 Januari 2019, dari Cheat Sheet: https://www.cheatsheet.com/health-fitness/a-new-study-finds-millennials-are-the-firstgeneration-on-track-to-be-less-healthy-than-their-parents-by-middle-age.html/

Permatasari, A. (3 April 2017). Generasi Milenial Kesulitan Interaksi Langsung. Diunduh 23 Januari 2019, dari VIVA: https://www.viva.co.id/gaya-hidup/kesehatan-intim/901082-generasimilenial-kesulitan-interaksi-langsung

Ramadhani, Y. (6 September 2018). Generasi Milenial Jakarta Lebih Memilih Huni Kos daripada Apartemen. Diunduh 24 Maret 2019, dari Tirto.id: https://tirto.id/generasi-milenial-jakartalebih-memilih-huni-kos-daripada-apartemen-cXiE

Razqa, S. M. (21 Juni 2018). Milenial Jadi Generasi dengan Tingkat Kesehatan Buruk. Diunduh 23 Januari 2019, dari Kumparan: https://kumparan.com/@kumparansains/milenial-jadi-generasidengan-tingkat-kesehatan-buruk

Sukada, B. A. (1984). Tipologi Arsitektur Tradisional sebagai pendekatan dalam perencanaan dan perancangan kampus Universitas Indonesia di Depok, Jawa Barat

Tjahjono, G. Metode Perancangan Suatu Pengantar untuk Arsitek dan Perancang.

Undang Undang Republik Indonesia Nomor 20 Tahun 2011 tentang Rumah Susun 
